\title{
Injuries prevalence in elite male artistic gymnasts
}

CDD. 20.ed. 796.024

796.41

http://dx.doi.org/10.1590/1807-55092016000100079

\author{
Natália Batista Albuquerque GOULART \\ Morgana LUNARDI ${ }^{* *}$ \\ Jennifer Faraon WALTRICK ${ }^{* * *}$ \\ Annelise LINK*** \\ Leandro GARCIAS ${ }^{* * * *}$ \\ Mônica de Oliveira MELO*** \\ João Carlos OLIVA**** \\ Marco Aurélio VAZ ${ }^{* * * * *}$
}

*Colegiado de Educação Física, Universidade Federal do Vale do São Francisco, Petrolina, PE, Brasil.

${ }^{* *}$ Centro de Desportos, Universidade Federal de Santa Catarina, Florianópolis, RS, Brasil.

${ }^{* * *}$ Centro de Ciências Biológicas e da Saúde, Universidade de Caxias do Sul, Caxias do Sul, RS, Brasil.

****Escola de Educação Física, Universidade Federal do Rio Grande do Sul, Porto Alegre, RS, Brasil.

The purpose of this study was to investigate the injuries prevalence in men elite artistic gymnasts. Twenty Brazilian senior gymnasts, aged $23.1 \pm 6.5$ years, $13.9 \pm 5.0$ years of practice and $36.5 \pm 4.7$ hours per week training, participated in this study. The athletes answered a morbidity questionnaire, formulated according to studies from the literature, for information on the injuries' characteristics and circumstances. Information about the injury circumstances (gymnastic apparatus, overload training and physical exercises), the anatomic site injured, the affect biological tissue and the return to training after injury treatment were evaluated. Data were analyzed by descriptive statistics, absolute and relative frequencies. The training overload, and floor, pommel horse and vault were the events that presented higher injuries frequency. In relation to anatomic site, ankle, hands/fingers and shoulder were the most cited regions. The ligament, bone and articular capsule were the most affected biological tissues. In relation to gymnasts' return to their sports activities, 56\% of them reported a better condition at return, 33\% reported to have returned at the same fitness level and 10\% indicated that they were in a worse condition when they returned to the sports activities. The men's artistic gymnastics injuries are related to the mechanical demands of this sport. The analysis of risk factors helps in understanding the injuries mechanisms in gymnastics, and provides relevant information that can assist in effective prevention strategies.

KeY WoRDS: Injury; Gymnastic; Training; Questionnaire.

\section{Introduction}

Men's artistic gymnastic (AG) is featured by the executions of high complexity skills to be performed in six different apparatus: floor exercise, pommel horse, rings, vault, parallel bars, and horizontal bar ${ }^{1}$. In recent years, $A G$ has shown great evolution due to materials and apparatus development, as well as to training methods improvement ${ }^{2-3}$. Such changes have increased the number of participants, due to a more attractive sport. However, improve in performance has been a result from more difficult elements created by the athletes (sometimes with the athlete's name being given to a specific movement). In addition, a more strict scoring system has resulted from these material, technical and performance improvements. All these factors might lead to a higher injury risk $\mathrm{k}^{4-5}$.

According to Nunomura ${ }^{4}$, each apparatus presents unique characteristics. Injuries are related to the movements performed on these apparatus, as well as to insufficient training, guidance and protection given to the gymnasts. However, the literature lacks a systematic study looking at the mechanisms and incidence of sports injury. Epidemiological studies in sports injuries are important strategies to identify risk factors and to set preventive measures against these injuries ${ }^{6-8}$. The literature presents a wide range of studies on the prevalence of injuries among female 
gymnasts. However, these studies rarely address injury occurrence in males. Thus, the current study aims to investigate the prevalence of injuries in men's artistic gymnastics, the gymnastic apparatus at which the injury occurred, the anatomical sites and the most affected biological tissues of these injuries.

\section{Method}

A total of 20 Brazilian senior men gymnasts participated in the current study. The gymnast group consisted of high performance (elite) gymnasts at national competition level. The present investigation was approved by the Ethics Committee on Human Research from the Federal University of Rio Grande do Sul (CAAE: 1 0059712.9.0000.5347). All gymnasts and trainers (in the case of young gymnasts) signed the informed consent form to participate in the study.

The athletes answered a morbidity questionnaire used to identify the injuries prevalence. The questionnaire was formulated according to epidemiological descriptive studies on gymnastics athletes found in the literature ${ }^{5-8}$. Interviews were conducted at the time the injury occurred or thereafter, during artistic gymnastic competitions or training sessions. The questionnaire included personal information such as age, time of training (in years) and weekly training hours. Athletes recorded injury information about its anatomical location, circumstance of injury (gymnastic apparatus) and about their return to training activities after injury treatment. In order to better classify the collected data, injuries were separated according to the affected biological tissue, using the following classification: bone injury, cartilage injury, ligament injury, tendon injury, muscle injury and capsular injury. In addition, two events found in the training routine were added to evaluate injury prevalence at the men's apparatus: overload training (related to repetitive effort of the musculoskeletal system due to gymnastic training) and warm up/physical preparation exercises. The participants answered the questions and the investigator, who was also in charge of making notes in the questionnaire, conducted the procedure.

On the current study, injury was considered as any gymnastics-related incident resulting from training and/or competition and able to cause the athlete's temporary suspension from the training routine or modification of all or part of his training as well as the need for medical treatment for at least a month ${ }^{8}$. Recorded data were systematically organized on Excel spreadsheets for analysis. Data on the injuries prevalence, their anatomical site, as well as the gymnastic apparatus where they occurred, were analyzed using descriptive statistics by absolute and relative frequencies distribution.

\section{Results}

Athletes had an average training time of about 14 years, with more than 35 hours of training per week (TABLE 1).

Injuries were located at the forearm (36\%), ankle joint (16.2\%), hand and fingers (14.4\%), shoulder (12.6\%), lower back $(9.0 \%)$, wrist $(8.1 \%)$ and groin/buttock and heel/toes/foot $(6.3 \%)$, elbow and knee (5.4\%) (TABLE 2).

According to the event, injuries were distributed on Floor (23.4\%), Pommel Horse (11.7\%),
Rings (8.1\%), Parallel Bars and Horizontal Bars (7.2\%), and Vault (11.7\%). Overload Training was responsible for $27 \%$ of the injuries, whereas Warm up/Physical Exercises accounted for 3.6\% (TABLE 3).

Regarding the biological tissues that were mostly affected, ligament injuries had the highest relative incidence $(28 \%)$, followed by bone $(26.6 \%)$, articular capsule (15.8\%), muscle (12.9\%), tendon $(10 \%)$ and cartilage $(6.4 \%)$ (TABLE 4$)$.

TABLE 1 -Gymnasts' age, training experience and training time variables.

\begin{tabular}{lccc}
\hline & Age & Training time & Weekly hours \\
\hline Mean $\pm S D$ & $23.1 \pm 6.5$ & $13.9 \pm 5.0$ & $36.5 \pm 4.7$ \\
\hline
\end{tabular}


TABLE 2 - Absolute (n) and relative (\%) injuries distribution regarding their anatomical site.

\begin{tabular}{lcc}
\hline Site & N. of injuries & $\%$ \\
\hline Head/Face & 1 & 0.9 \\
Neck & 1 & 0.9 \\
\hline Upper Back & 0 & 0.0 \\
Lower Back & 10 & 9.0 \\
Pelvis/Hips & 1 & 0.9 \\
Abdomen & 2 & 1.8 \\
\hline Shoulder & 14 & 12.6 \\
Arm & 4 & 3.6 \\
Forearm & 4 & 3.6 \\
Elbow & 6 & 5.4 \\
Wrist & 9 & 8.1 \\
Hand/fingers & 16 & 14.4 \\
\hline Groin/buttock & 7 & 6.3 \\
Thigh & 2 & 2.7 \\
Knee & 6 & 5.4 \\
Lower Leg & 1 & 0.9 \\
Calf & 2 & 1.8 \\
Ankle & 18 & 16.2 \\
Heel/Toes/Foot & 7 & 6.3 \\
\hline Total & 111 & 100 \\
\hline
\end{tabular}

TABLE 3 - Absolute (n) and relative (\%) injuries distribution according to the event.

\begin{tabular}{|c|c|c|c|c|c|c|c|c|}
\hline Site & FL & $\mathbf{P H}$ & RI & PB & HB & VA & OT & PE \\
\hline Head/Face & & & & & & & & 1 \\
\hline Neck & & & & & & 1 & & \\
\hline \multicolumn{9}{|l|}{ Upper Back } \\
\hline Lower Back & & & & 1 & & 1 & 8 & \\
\hline Pelvis/Hips & & & & & & 1 & & \\
\hline Abdomen & & & & & & & & 2 \\
\hline Shoulder & & & 4 & 2 & & & 8 & \\
\hline Arm & 1 & & 1 & & 1 & & 1 & \\
\hline Forearm & & 2 & & & & & 2 & \\
\hline Elbow & 2 & & 1 & & & & 3 & \\
\hline Wrist & & 4 & 1 & & & & 4 & \\
\hline Hand/finger & 2 & 6 & & 4 & 3 & & 1 & \\
\hline Groin/buttock & 3 & & & & 2 & 1 & 1 & \\
\hline Thigh & 1 & & & & 1 & & & \\
\hline Knee & 3 & & & & & 1 & 1 & 1 \\
\hline Lower Leg & 1 & & & & & & & \\
\hline Calf & 1 & & & & & & & 1 \\
\hline Ankle & 7 & 1 & 2 & 1 & 1 & 6 & & \\
\hline Heel/Toes/Foot & 5 & & & & & 2 & & \\
\hline Total Injuries & 26 & 13 & 9 & 8 & 8 & 13 & 30 & 4 \\
\hline$\%$ & 23.4 & 11.7 & 8.1 & 7.2 & 7.2 & 11.7 & 27.0 & 3.6 \\
\hline
\end{tabular}

FL: Floor;

PH: Pommel Horse; Rl: Rings;

PB: Parallel Bars;

HB: Horizontal Bars;

VA: Vault;

OT: Overload Training; PE: Warm up/ Physical Exercises. 
TABLE 4 - Events related to artistic gymnastic training and the affected biological tissue.

FL: Floor;

PH: Pommel Horse;

Rl: Rings;

PB: Parallel Bars;

HB: Horizontal Bars

VA: Vault;

OT: Overload Training;

PE: Warm up/ Physical

Exercises.

\begin{tabular}{|c|c|c|c|c|c|c|}
\hline & Bone & Cartilage & Ligament & Tendon & Muscle & Articular capsule \\
\hline FL & 13 & 1 & 13 & 2 & 6 & \\
\hline $\mathrm{PH}$ & 8 & & 7 & & 1 & \\
\hline RI & 1 & & 4 & 1 & 2 & 6 \\
\hline $\mathrm{PB}$ & 3 & & 4 & & 1 & \\
\hline $\mathrm{HB}$ & 2 & 1 & 2 & & 4 & 1 \\
\hline VA & 5 & & 8 & 1 & 2 & \\
\hline OT & 2 & 6 & & 10 & & 15 \\
\hline PE & & 1 & 1 & & 2 & \\
\hline Total & 37 & 9 & 39 & 14 & 18 & 22 \\
\hline$\%$ & 26.6 & 6.4 & 28.0 & 10.0 & 12.9 & 15.8 \\
\hline
\end{tabular}

\section{Discussion}

AG is associated with intensive movement repetition to achieve a precise execution of the different exercises. Moreover, in recent years, complexity increased in their implementation and motor demand, fact that determined an increase in daily training hours ${ }^{2,6}$. In this study, injuries caused by overload training presented the highest percentage of reports. DALY et al. ${ }^{9}$ reported that fatigue was a major factor contribution to injury in elite gymnasts. They are more often found at the shoulders and in the lower back. Micheli and Allison ${ }^{10}$ reported that lower back injuries are usually related to acute microtrauma (single traumatic event) or successive microtrauma events (overuse). Such events result from repetitive flexions and extensions due to spine rotation in gymnastics movements. AG, just as other sports, works with an intense calendar of important competitions. Sometimes the athlete does not have time to physically recover for the next competition, as it is required.

In addition to overload training, floor, pommel horse and vault also lead to high injury occurrence, respectively. Floor is the most complex AG apparatus and it is composed of acrobatic elements combined with gymnastic strength and balance exercises ${ }^{11}$. Floor exercise demands are linked to strength (muscle power in the lower and upper limbs), flexibility, and muscular anaerobic endurance. It may be noticed that injuries caused by this device are found in different joints due to its complexity and the injuries are mostly concentrated in the lower limbs ${ }^{4,6}$. On the other hand, the pommel horse predominantly uses the strength of the upper limbs, since the athlete's weight is fully supported on the hand ${ }^{11}$.

Gymnasts must execute all elements without interruptions, which demands high anaerobic and muscular endurance, rhythm and balance on the upper limbs ${ }^{6,11}$. These exercises may be associated with the high percentage of injuries in wrists, hands and fingers. As for the vault exercise, each vault begins with the preparatory running ( 25 meters), continues with a take-off from both feet to the springboard, a support phase on the table with two hands (first phase), and the second flight phase involves the pushing off from the table up to landing in a standing position ${ }^{12}$. Thus, vault leads to high rates of injuries located in the ankle, especially caused by the landing movements $s^{6,13}$.

In relation to anatomic site, ankle, hands/fingers and shoulder were the most cited regions. By analyzing the movements performed on each men's artistic gymnastics unit, it was possible to conclude that the ankle is the most demanded joint in landing, mainly on the floor and vault apparatus ${ }^{6,14}$. Nunomura ${ }^{4}$ reports that most ankle injuries occur due to unsuccessful landing. The gymnast must be able to control the ground reaction force, using biomechanical and neuromuscular strategies (biarticular muscle activation) during the landing procedure ${ }^{13-15}$. According to the literature, teaching the correct and controlled movement, and using exercises for the lower limbs are important strategies to prevent and minimize injuries ${ }^{15-17}$.

In addition, hands and fingers also present high injury incidence since much of the exercises in men's 
devices involve suspension and body support on these structures. According to literature ${ }^{4,8}$, the hand and finger injuries go from acute events, such as blisters and abrasions, to the most complex ones, such as dislocations and fractures, as it was herein mentioned.

Finally, the shoulder joint is also often injured, mainly due to movements performed in the rings. According to Carrara and Mochigueki ${ }^{18}$, most movements in the rings require shoulder abduction and consequent capsular compression in order to keep joint stability. Thus, many injuries suffered in this unit are due to inflammation in the shoulder joint capsule.

The current study also aimed to evaluate the tissues presenting the highest injury prevalence in men's AG. The ligament tissue presented the biggest number of cases, usually due to sprains. According to the report of the athletes themselves, these injuries are mostly caused by the floor apparatus, and they often occur after successive jumps or incorrect landings ${ }^{6,8}$. Ligaments, despite being adaptable and flexible, allow natural movement of the bones they are connected to. They do not present major force resistance under sprain loads ${ }^{19}$. Thus, it results in the partial rupture of this tissue and in the longer overall time required to treat it.

In addition to the ligament tissue, bone tissue injuries were also quite cited by the athletes. According to the results, they occur due to fractures in the feet, toes as well as in the hands and fingers. Bone tissue is a specialized structural tissue and its solid composition adapts to the support functions and to its protection ${ }^{20}$. According to the literature, bone injuries have affected athletes due to the strong impact of the exercises required by the artistic gymnastics ${ }^{6,20}$. Therefore, it is worth teaching right landing technique, since the movement must be done on both feet or on both hands in order to dissipate power impact on the structures ${ }^{13,16}$.

Finally, the injuries in the articular capsule are also among the three most cited tissues and it is due to the overload training and, in some cases, to specific ring exercises, as it was previously mentioned. Among this group of injuries, it is worth highlighting those located in the anterosuperior top and on the posterosuperior shoulder labrum (SLAP). These injuries usually occur in the insertion zone, over the biceps tendon, due to the biomechanical overload exerted by the shoulders rotation and abduction movements ${ }^{21-22}$. CARRARA and MoCHIGUEKI ${ }^{18}$ report that many athletes present shoulder instability, thus training sessions should involve strengthening of shoulder muscles that are related to dynamic stabilization of this joint, especially the rotator cuff.
Biological tissue response is influenced by tissue age, tissue fatigue, mechanical tissue properties, and other factors ${ }^{19}$. Therefore, athletes and coaches must know some clinical aspects that occur in skeletal tissues following trauma, as well as the fact that the affected tissue requires different treatment modalities (immobilization, surgical treatments, infiltrations) to keep the segment from any other injuries. In this study, the athletes reported that some injuries severely affected more than one tissue.

The injuries in AG show complex etiology; however, Nunomura ${ }^{4}$ points out that the role played by health professionals such as physical educators, physiotherapists and medical doctors may reduce injury risks and allow faster recovery and the gymnasts' safe return to sports practice. Besides the basic precautions involving injuries, the biomechanical studies have provided theoretical data in such extent that the skills needed to prevent injury and prolong the athlete's career in sport are more properly applied.

Regarding the conditions required to the gymnasts' return to sports practice after treatment, $56 \%$ of them have reported better return, 33\% reported to have returned at the same fitness level as pre-injury and $10 \%$ have reported to be worse fitted when they returned to sports practice. During the rehabilitation period, after the injury was healed, the athletes must change their training habits and improve their skeletal tissues conditioning in order to enable their efficient recovery ${ }^{23}$. According to the current study, most athletes reported better conditioning after the recovery period. Such result is linked to the strengthening exercises used in rehabilitation and to reduced training load, as well as to training and improved strengthening techniques.

In the current study, the athletes had difficulty remembering previous injuries. On the other hand, they reported that it was easier to remember the latest events or those that have marked their careers. In addition, the difficulty athletes have to be properly diagnosed for certain injuries by clinical professionals was also shown in the current study. Therefore, it is also important to have the participation of these health professionals (such as physiotherapist or coach) to answer information regarding athletes' injuries.

The current study presents the following conclusions:

- Most injuries in men's artistic gymnastics are due to overload training and to moves on floor, pommel horse and vault; 
- The anatomical sites with highest injury prevalence in men's artistic gymnastics are: ankle, hands, fingers and shoulders;

- Biological tissues presenting higher injury prevalence in men's artistic gymnastics are: ligament tissue, bone and articular capsule of the shoulder joint.

Thus, studies focused on analyzing risk factors associated with injuries are critical for a better understanding on the occurrence mechanisms as well as to boost the development of more specific prevention programs for AG. Data in the current study showed that injuries in AG mostly occur because of physical stress due to training and/ or overtraining. Therefore, 1) a good physical preparation, including valences such as strength, speed, power, flexibility and resistance of all muscle groups associated with the training; 2 ) a thorough multidisciplinary physical/clinical examination prior to competition season involving the coach, the physiotherapist, the medical doctor, the nutritionist and the psychologist; and 3) the study of injury mechanisms and the development of prevention programs, especially for the apparatus that involves landing and body support, may all lead to significant results regarding injury prevention and performance improvement.

\section{Resumo}

Prevalência de lesões na ginástica artística masculina de alto rendimento

A proposta deste estudo foi investigar a prevalência de lesões na ginástica artística masculina de alto rendimento. Vinte ginastas brasileiros da categoria adulta, com 23,1 $\pm 6,5$ anos, $13,9 \pm 5,0$ anos de prática no esporte e $36,5 \pm 4,7$ horas de treino semanais, participaram do estudo. Os atletas responderam 0 questionário de lesões referidas, formulado a partir de estudos da literatura, para obter informações sobre as características e circunstâncias das lesões. Foram considerados dados sobre o aparelho ou evento do treinamento em que ocorreu a lesão, o local anatômico lesionado, o tecido biológico afetado e o retorno às atividades após a lesão. Os dados foram avaliados por meio de estatística descritiva, a partir das frequências absolutas e relativas. A sobrecarga de treinamento e os aparelhos solo, cavalo com alças e salto sobre a mesa foram os eventos com maior frequência de lesões. Em relação ao local anatômico, tornozelo, mãos/dedos e ombro foram as regiões mais citadas. Os tecidos ligamentares e ósseo, bem como a cápsula articular foram os tecidos biológicos mais afetados. Em relação ao retorno às atividades, $56 \%$ relataram melhora, 33\% reportaram retorno ao mesmo nível prévio à lesão e 10\% relataram piora do desempenho após retorno às atividades. As lesões na ginástica artística masculina estão associadas às demandas mecânicas do esporte. A análise dos fatores de risco contribui no entendimento dos mecanismos das lesões na ginástica, bem como pode auxiliar em estratégias efetivas de prevenção.

Palavras-chave: Lesão; Ginástica; Treinamento; Questionário.

\section{References}

1. Oliveira MS, Bortoleto MAC. Apontamentos sobre a evoluçâo histórica, material e morfológica dos aparelhos da ginástica artística masculina. Rev Educ Fís. 2011;22:283-95.

2. Nunomura M, Pires RF, Carrara P. Análise do treinamento da ginástica artística brasileira. Rev Bras Cienc Esporte. 2009;31:25-40.

3. Schiavon LM, Paes RR, Toledo E, et al. Panorama da ginástica artística feminina brasileira de alto rendimento esportivo: progressão, realidade e necessidades. Rev Bras Educ Fís Esporte. 2013;227:423-36.

4. Nunomura M. Lesóes na ginástica artística: principais incidências e medidas preventivas. Motriz. 2002;8:21-29.

5. Hoshi RA, Pastre CM, Vanderlei LCM, et al. Rev Bras Med Esporte. Lesões desportivas na ginástica artística: estudo a partir de morbidade referida. Rev Bras Med Esporte. 2008;14:440-45.

6. Caine DJ, Russel K, Lim L. Handbook of sports medicine and science: gymnastics. Oxford: United Kingdom; 2013. 
7. Grigore V, Cosma G, Paunescu M. Retrospective study regarding artistic gymnastic injuries. Procedia Soc Behav Sci. 2014; 17:45-49.

8. Dennis C, Kathy K, Warren H, et al. A three-year epidemiological study of injuries affecting young female gymnasts. Phys Ther Sport. 2003;4:10-23.

9. Daly RM, Bass SL, Finch CF. Balancing the risk of injury to gymnasts: how effective are the counter measures? Br J Sports Med. 2001;35:8-20.

10. Micheli LJ, Allison G. Lumbar spine injury in the young athlete. Rev Bras Med Esporte. 1999;5:59-65.

11. Nunomura M. Ginástica artística. São Paulo: Odysseus; 2008.

12. Federation Internationale de Gymnastique. Code of points of men’s artistic gymnastic 2013-2016. Lausanne: FIG; 2013.

13. Gittoes MJ, Irwin G. Biomechanical approaches to understanding the potentially injurious demands of gymnastic-style impact landings. Sports Med Arthrosc Rehabil Ther Technol. 2012;4:1-9.

14. Mcnitt-Gray JL, Mechanical demand and multijoint control during landing depend on orientation of the body segments relative to the reaction force. J Biomech. 2001;34:1471-82.

15. Kirialanis P, Malliou P, Beneka A, et al. Occurrence of acute lower limb injuries in artistic gymnasts in relation to event and exercise phase. Br J Sports Med. 2003;37:137-9.

16. Marinšek M. Basic landing characteristics and their implication. Sci Gymnastics J. 2011;2:59-67.

17. Cuk II, Marinsek M. Landing quality in artistic gymnastics is related to landing symmetry. Biol Sport. 2013;30:29-33.

18. Carrara P, Mochigueki, L. Análise biomecânica do crucifixo nas argolas. R. Bras Ci Mov. 2008;16:83-91.

19. Nordin M, Frankel VH. Biomecânica básica do sistema musculoesquelético. 3a ed. Rio de Janeiro: Guanabara Koogan; 2003.

20. Nakamoto JC, Saito M, Cunha AP, et al. Fratura do escafoide por estresse em ginasta: relato de caso. Rev Bras Ortop. 2009;44:533-5.

21. Godinho GG, Freitas JMA, Leite LMB, et al. Lesóes slap no ombro. Rev Bras Ortop. 1998;33:345-52.

22. Silva RT. Lesóes do membro superior no esporte. Rev Bras Ortop. 2010;45:122-31.

23. Prentice WE. Modalidades terapêuticas em medicina esportiva. São Paulo: Manole; 2002.

\begin{tabular}{|c|c|}
\hline $\begin{array}{r}\text { ENDEREÇo } \\
\text { Natália Batista Albuquerque Goulart } \\
\text { Colegiado de Educação Física } \\
\text { Universidade Federal do Vale do São Francisco } \\
\text { Av. José de Sá Maniçoba, s/n - Campus Universitário } \\
\text { 56304-917 - Petrolina - PE - BRASIL } \\
\text { e-mail: natalia.goulart@univasf.edu.br }\end{array}$ & $\begin{array}{l}\text { Recebido para publicação: 25/11/2015 } \\
\text { Aceito: 14/12/2015 }\end{array}$ \\
\hline
\end{tabular}

